\title{
6 Always the hero to ourselves The role of self-deception in unethical behavior
}

\section{Celia Moore}

\begin{abstract}
Number one and foremost, I threw my whole life and lived my life in a certain way to make sure that I would never violate any law - certainly never any criminal laws - and always maintained that most important to me was my integrity, was my character, were my values, and then - and have always taken that very seriously.
\end{abstract}

-Former Enron CEO Ken Lay

Many people would doubt Ken Lay's sincerity as he claimed, during a 2004 interview on CNN, that what he valued most about himself was his integrity. Many people, that is, except Lay himself, who likely felt wholeheartedly sincere when he said so. Humans have a deep-seated need to see themselves in a positive light (Greenwald, 1980), a need that is particularly acute in the moral domain (Blasi, 1984). Nearly everyone believes strongly that they are moral and holds the view that their actions are appropriate, honorable, and fair (Allison, Messick, \& Goethals, 1989; Messick, Bloom, Boldizar, \& Samuelson, 1985; Van Lange \& Sedikides, 1998). In other words, we are the heroes of our own narratives. However, this common belief sits uncomfortably with the fact that most of us behave, with distressing frequency, in ways that are inappropriate, dishonorable, and unfair (Ariely, 2012; Callahan, 2004; Gabor, 1994). We resolve this common contradiction - that we often in fact behave in ways that we like to think we don't - through self-deception, "the active misrepresentation of reality to the conscious mind" (Trivers, 2000, p. 114). This chapter is about the way in which self-deception supports our ability to think of ourselves as the hero of our own narratives, when in fact we have been anything but.

\section{The origins of research on self-deception}

The topic of self-deception was originally the domain of philosophers. Their main interest was in the epistemological paradox that strict understandings of self-deception represent (Fingarette, 1969; Haight, 1980; Mele, 2001). In its most literal sense, self-deception is a logical fallacy, as 
it requires someone to simultaneously know and not know something to be true. However, denying that self-deception exists depends upon a number of assumptions about the nature of human knowledge, most notably that we are conscious of all of our beliefs at all times. Since Freud (1900/1955) introduced the idea that human perception, information processing, storage, and retrieval could be motivated as well as function on multiple levels of consciousness, psychological theory has questioned whether human knowledge is best understood as monolithic in this way. Once psychologists opened up the possibility that selfdeception might mean something other than consciously and simultaneously holding two contradictory beliefs, efforts to demonstrate it began to show various ways in which we can trick ourselves into believing what we want to believe and trick ourselves out of confronting what we would rather not admit about ourselves.

Gur and Sackheim (1979) published the first effort to demonstrate selfdeception empirically. Their experiments were designed to demonstrate the following classic criteria of self-deception: (1) that an individual holds two contradictory beliefs, (2) simultaneously, (3) without being aware of doing so, and that (4) this is a motivated act. Using a clever paradigm, they had participants record their own voices, and then listen to thirty audio clips, of both their own and others' voices, with instructions to indicate which clips were recordings of their own voice. They also tracked participants' galvanic skin responses (GSR) while doing so. They were interested in instances when one misidentified another's voice as one's own (narcissistic self-deception), or misidentified one's own voice as another's (self-avoidant self-deception). They made the argument that high GSR levels represented an unconscious awareness of one's own voice, since individuals show higher levels of GSR when confronted with themselves compared to others (1979). They found that when participants heard their own voice, GSR levels remained steady, regardless of whether or not they consciously identified the voice as their own. The authors claim that these results show that individuals accurately recognized their own voice unconsciously, even when they did not always identify it at a conscious level.

\section{Self-deception in unethical behavior}

Of course, the moral implications of disavowing one's own voice or identifying another's voice as one's own are not necessarily obvious. However, it is easier to make the case for the relevance of this research to moral psychology when one realizes that the participants' voice misidentifications were motivated by whether the self was positively or 
negatively regarded. In Gur and Sackheim's final experiment, individuals whose self-esteem had been temporarily boosted (making self-confrontation less aversive) were more likely to misidentify others' voices as their own, while individuals whose self-esteem had been threatened (making selfconfrontation more aversive) were more likely to identify their own voice as someone else's (1979). This final study showed that one's conscious beliefs about whether the voice they were hearing was their own were motivated by whether the participants felt positively or negatively about themselves at the time. If the tendency to believe that one caused an action oneself increases when that action has positive mental associations, and the tendency to believe that someone else caused an action increases when that action has negative mental associations, then it becomes easier to see how self-deception might facilitate unethical behavior. The same mental processes that support the conscious belief that our voice is not our own when the self feels aversive support our conscious disavowals of our own immoral actions (Tenbrunsel \& Messick, 2004).

Several scholars have noted the usefulness of self-deception in facilitating unethical behavior (Levy, 2004; Lu \& Chang, 2011; Martin, 1986; Rick et al., 2008; Tenbrunsel, Diekmann, Wade-Benzoni, \& Bazerman, 2010; Tenbrunsel \& Messick, 2004). The deep-seated need to see ourselves as moral while we behave in morally compromised ways causes a misalignment between our actions and our beliefs about ourselves, leading to the aversive state known as cognitive dissonance (Festinger, 1957; Festinger \& Freedman, 1964). Resolving dissonance requires that we either change our behavior to align more closely with our beliefs, or change our beliefs to align more closely with our behavior. Since it is easier to change beliefs than to change behavior, we tend to resolve dissonance through changing our beliefs (Cooper, 2007). This is particularly convenient in the moral domain, as changing our moral beliefs allows us behave unethically without tarnishing our moral self-image.

Most research on self-deception does not provide evidence of two simultaneously held contradictory beliefs, as the criteria for selfdeception proposed by Gur and Sackheim require. Rather, psychological work on self-deception has focused on the various strategies that individuals employ when faced with a potential misalignment between their morally questionable behavior and their belief that they are moral. These self-deceptive strategies tend to take one of three forms, together representing what Tenbrunsel and Messick call our "internal con game," which "allow one to behave self-interestedly while, at the same time, falsely believing that one's moral principles were upheld" (2004, p. 223).

The first of these strategies involves motivated attention. This selfdeceptive strategy involves (1) under-attending to evidence that 
undermines our beliefs about ourselves as moral and (2) over-attending to evidence that supports our heroic beliefs about ourselves. This strategy throws a spotlight on what we like to know about ourselves and keeps what we'd prefer not to know about ourselves in the shadows.

The second of these strategies involves motivated construal. In this selfdeceptive strategy, we are aware of the objective reality of our own morally problematic behavior but find ways to redefine it as morally innocuous (or at least morally justified). We accomplish this through (3) reframing the act as acceptable or (4) minimizing our responsibility for it and (5) exploiting situational ambiguity to our advantage.

The third of these strategies involves motivated recall. This selfdeceptive strategy mirrors motivated attention, except that it involves (6) forgetting what we'd rather not know about ourselves and (7) inventing self-serving versions of past events, even to the point of creating memories of past events that never occurred. Since our self-image depends heavily on how we make sense of our past behavior, these strategies can be particularly useful in editing our personal narratives to ensure that we can claim that the most important thing to us is our integrity, and feel sincere as we do so, even when our actions do not support this belief. Just like Ken Lay was able to, even as he was being convicted of several counts of securities fraud.

\section{Motivated attention}

The primary way that individuals deceive themselves about the status of future behavior is to find ways to refrain from telling themselves the whole truth about their behavior or its potential consequences (von Hippel \& Trivers, 2011, p. 7). This typically involves directing our attention to what we most want to believe, either by actively searching for information that allows us to define our actions as more morally appropriate than they are or by avoiding information that would force us to confront the moral status of our actions.

(1) Overattention to evidence that supports moral self-views. Individuals often self-deceive through motivated information search strategies, cutting information search short once one has the information one is looking for, or continuing information search if one hasn't yet heard what one wants. These strategies are often grouped under the rubric of confirmation bias (Nickerson, 1998). Classic demonstrations of motivated information search to support preferred beliefs about the self used paradigms involving personal health. In these studies, individuals given unfavorable diagnoses were more likely to retest the validity of the result, and evaluate the test as less accurate, compared to those given 
favorable diagnoses (Ditto \& Lopez, 1992; Ditto, Munro, Apanovitch, Scepansky, \& Lockhart, 2003). In one study, individuals waited $60 \%$ longer for a saliva test strip to change color when they had been led to believe that a color change revealed positive information about one's health, compared to when they had been led to believe that it indicated disease (Ditto \& Lopez, 1992). Motivated information search has been shown to be particularly pernicious in the legal domain, where expectations about an alleged perpetrator's guilt or innocence has been shown to drive how investigators question suspects, and, as a result, affect the likelihood that they will be considered guilty (Hill, Memon, \& McGeorge, 2008; O’Brien, 2009).

It is easy to see how motivated information search would be useful in supporting unethical behavior. During a scandal that rocked HewlettPackard in the mid-2000s, the private detectives hired to identify the board member leaking corporate strategy to the media impersonated various board members in order to access their personal phone records. Senior officials within Hewlett-Packard associated with the investigation sought frequent reassurance from the legal department that the use of this strategy, called pretexting, was within the bounds of the law. They kept asking until they heard what they wanted to hear: that doing so wasn't technically illegal (Stewart, 2007). They then overvalued this legal advice over the more tentative advice they had received earlier, considering it the final word on the practice. Actively seeking evidence that pretexting was within the bounds of the law, and then giving preferential treatment to evidence supporting this desired belief - are both instances of confirmation bias that supported the executives' beliefs that what they were doing was acceptable.

The need to see ourselves as morally upstanding can be so great that we will go beyond the mere search for information that supports this belief, and actively construct evidence to support it. Evidence of this comes from another early study of self-deception, in which subjects were informed that individuals with healthy hearts could sustain their arm being submerged in extremely cold water for either a very long or very short period of time (Quattrone \& Tversky, 1984). Compared to baseline tolerance levels, $71 \%$ of participants shifted tolerance for cold water in the direction that indicated they would live a long and healthy life, even when that meant keeping their arm submerged for longer than they had just claimed was their highest tolerance level. Moreover, the majority of participants denied trying to shift their tolerance levels in the direction that would indicate a healthy heart. In other words, they inflicted pain on themselves in order to create evidence to support the desired belief that they had a "healthy" heart, even as they denied they were doing so. 
(2) Avoidance of evidence that undermines moral self-views. In addition to shining a light on evidence that supports our preferred beliefs about ourselves, we also disproportionally neglect information that may undermine our moral self-image. Avoiding information we prefer not to know allows us to maintain plausible deniability to ourselves about our actions, and helps us dodge confronting our ethical failures, while allowing us to receive the benefits that unethical behavior often brings to us personally. This self-deception strategy has been called "willful ignorance," and has been most commonly studied in health contexts. For example, individuals avoid being tested for medical conditions they believe are untreatable (Dawson, Savitsky, \& Dunning, 2006).

Ethically motivated willful ignorance has also been demonstrated. Ehrich and Irwin (2005) studied willful ignorance in the context of consumer choice and showed that individuals under-request information about the ethical attributes of a desirable product if that information is important to them. Intentionally avoiding potentially damning information about a pending purchase allows individuals to buy it without having to face unpleasant details about how that product was manufactured. Sweeny and colleagues offer three primary reasons why individuals may be motivated to avoid information in this way (Sweeny, Melnyk, Miller, \& Shepperd, 2010). First, avoiding information allows individuals to maintain beliefs that might otherwise be threatened (such as "I am an ethical consumer"). Second, avoidance allows us to act in ways that they might otherwise feel compelled to refrain from (such as buying the morally problematic product). And finally, avoidance allows us to avoid unpleasant emotions elicited by the action (such as guilt or shame for having bought it).

One can see how all three of these reasons also played out for David Kugel, a longtime trader for Ponzi-schemer Bernie Madoff. We know now that, as far back as the 1980s, Madoff created fictitious trading reports that claimed consistently high and stable investment returns, while using investors' capital to pay out customers when they wanted to withdraw - robbing Peter to pay Paul. As one of his closest colleagues, Kugel's trial testimony makes clear that he avoided questioning Madoff about the source of his investment returns (Hays \& Neumeister, 2013). By ensuring he didn't know the whole truth about Madoff's fraud, he was able to (1) maintain the belief that he was not participating in a fraud, (2) engage in activity that generated significant financial returns for himself personally, and (3) avoid the unpleasant emotion of guilt while doing so.

Our need to see ourselves in a positive light means that we will both actively avoid evidence that undermines this belief, as well as actively seek evidence that supports it. While these strategies may not mean that we 
consciously hold the truth in mind while attending to preferred information, it does mean that we act "in ways that keep one uninformed about unwanted information," rendering the "knowable unknown" (Bandura, 2011, p. 16), thus ensuring we do not confront the truth about our behavior.

\section{Motivated construal}

The second way we deceive ourselves about unethical behavior involves the nature of the behavior itself and the way we understand our responsibility for it. This strategy does not require actively seeking evidence that supports our moral self-image, or actively avoiding evidence that would be difficult to square with seeing ourselves as moral. Instead, it involves construing immoral behavior as morally unproblematic. We do this by (3) framing the behavior as acceptable, (4) minimizing how we understand our responsibility for it, and (5) taking advantage of situational ambiguity to interpret the behavior in a preferred way. All of these strategies allow us to understand our behavior in a way that tempers its less savory elements, allowing us to avoid confronting how it challenges our ability to think of ourselves as moral.

(3) Framing our actions as morally acceptable. It is difficult to participate in behavior that we know to be unethical, as to do so undermines our ability to maintain a positive moral self-image. One might think it is only possible to knowingly engage in unethical behavior while maintaining it isn't through blatant insincerity - as one might suspect of Ken Lay as he proclaimed how important his integrity was to him. However, individuals are adept at construing their actions, whatever they are, as morally innocuous - or at the least, morally justifiable - even though they may very clearly violate moral principles that the individual consciously and actively values. Mills (1958) showed this in a study of schoolchildren nearly sixty years ago. First, he solicited the children's views about cheating. Then he gave them an opportunity to cheat. The views of those who cheated (particularly those who did so with the promise of only a small reward) became substantially more lenient after cheating.

How does this reframing occur in action? Recently, an MBA student I taught wrote an essay for my class in which he clearly stated that theft was wrong and that he would never steal. In the next paragraph, he confessed that, every day, he took the newspaper without paying for it every day from Starbucks. He claimed this was not theft, but rather a justified act of retaliation against a greedy corporation that charged too much for their coffee. When I pointed out to him that these two positions were logically inconsistent - encouraging him to confront the 
objective reality that taking the newspaper without paying for it is theft he reiterated that taking the newspaper was not theft, because he wouldn't steal. Rather, taking the paper allowed him to get "one up on this huge money sucking organization," "preventing a bad organization from earning the most minute and irrelevant of costs." I detected no insincerity in his comments. He did truly believe that theft was wrong, but very clearly excluded taking the newspaper without paying for it from this immoral category.

When we cannot deny having engaged in a behavior (in this example, taking the newspaper without paying for it), the only route available to us that allows us to maintain our positive moral self-image is to define that behavior as morally innocuous or justifiable. My student neutralized the cognitive dissonance he would have experienced if he had construed taking the newspaper as theft through a series of cognitive mechanisms that Albert Bandura termed moral disengagement (1990). These mechanisms include moral justification (thinking of one's action as meeting a higher purpose, such as when my student considered theft of the paper as "preventing a bad organization from earning"), distorting consequences (thinking of the theft as insignificant, calling it "minute and irrelevant"), euphemistic labeling (using exonerating language to support thinking of the act as morally innocuous, such as when the student called the decision to steal the paper on a daily basis "a new Starbucks purchasing policy"). Moral disengagement allows us to engage in unethical behavior while believing it is moral, and facility in using these mechanisms is associated with a host of unethical behaviors, from cheating on tests to violent criminality (for a review, see Moore, 2015).

Though Bandura denies that moral disengagement requires literal selfdeception, he does acknowledge that when individuals are confronted with evidence that would dispute their ability to maintain positive moral self-regard, moral disengagement allows them to "question its credibility, dismiss its relevance, or twist it to fit their views" (Bandura, 1991, p. 95). Thus, while the act of morally disengaging may not meet the strict criteria of self-deception that confound the philosophers - actively believing what one consciously knows to be false - it does meet the definition of selfdeception put forward by Trivers, "the active misrepresentation of reality to the conscious mind" (2000, p. 114). To deceive himself about the moral status of his actions, my former MBA student twisted his understanding of what taking the newspaper from Starbucks meant, using morally disengaged logic so that it didn't fall into a category he actively holds as morally problematic.

Research supports the idea that self-exonerating construals of our immoral acts are motivated by our desire to ensure our positive moral 
self-image (Mazar, Amir, \& Ariely, 2008). This work shows that when exonerating justifications are available, unethical behavior increases (Shalvi, Dana, Handgraaf, \& De Dreu, 2011), and when the opportunity to use exonerating logic is hampered, unethical behavior decreases (Bersoff, 1999). In Shalvi and colleagues' work (2011), participants were paid based on the outcome of a die roll, receiving in dollars the number they reported rolling on the die. In some conditions, participants only rolled the die once; in other conditions, they rolled the die multiple times, but were instructed to report only the outcome of the first roll. Participants were more likely to lie when they had rolled the die multiple times, and particularly when one of their "uncounted" rolls was a high number, as this provided them with a "desired counterfactual." The presence of the desired counterfactual put the thought "I almost got a high number" into their head, and supported overreporting their first die roll with less harm to their moral self-image.

Conversely, Bersoff (1999) tested whether removing obvious avenues of exonerating logic would decrease unethical behavior. He showed that participants were less likely to keep an experimenter's overpayment in circumstances that impaired participants' ability to construct neutralizing rationalizations for keeping the extra money. When participants were informed a student's personal funds were bankrolling the experiment, or when participants were asked directly whether they had just been paid the correct amount, it became more difficult for them to trick themselves into thinking that keeping the overpayment was acceptable and made them less likely to do so (Bersoff, 1999).

(4) Minimizing one's responsibility for the act. It can sometimes be easier to minimize the extent to which we consider ourselves morally responsible for our actions than it is to reconstrue the actions themselves as morally unproblematic. Thus, another way that we misrepresent reality to ourselves is by denying that we were responsible for our own behavior. This route to self-deception involves denying personal responsibility for actions that we clearly undertook.

It is a basic truth in social psychology that we make internal attributions about positive outcomes (believing we caused them) and external attributions for negative outcomes (believing that external factors caused them) (Arkin, Cooper, \& Kolditz, 1980; Zuckerman, 1979). In addition, our tendency to make self-serving attributions about the causes of our behavior increases to the extent that our ego is involved in the outcome (Miller, 1976).We are actually more likely to elicit any causal reasoning about negative outcomes than positive outcomes, perhaps to support the self-deception that we aren't the causal agents of negative outcomes (Taylor, 1991). 
Given that unethical behavior is a negative outcome with particular relevance to our egos, we are particularly motivated to make external attributions about the unethical outcomes we cause. Ken Lay, for example, blamed short sellers, a nervous stock market, and negative press for Enron's failings - anything except that, as CEO, he likely played a role in the company's failure (New York Times, 2006). A study of collegiate cheating also showed in a clever way our tendency to misattribute the causes of our bad behavior to external sources (Forsyth, Pope, \& McMillan, 1985). The researchers created an experimental paradigm in which participants either cheated actively or merely observed a confederate cheating. When participants cheated themselves, they were more likely to make external attributions for their actions and more likely to see those actions as unrepresentative of their typical behavior, than when they did not cheat (Forsyth et al., 1985).

Two mechanisms of moral disengagement - displacement and diffusion of responsibility - support self-serving attributions about the causes of events (Kunda, 1987; Miller \& Ross, 1975). Displacement of responsibility occurs when individuals attribute responsibility for their actions to an authority figure rather than themselves. Milgram's studies on obedience to authority revealed how individuals were able to inflict pain on others so long as they were able to think of the authority figure as the person, ultimately, to blame for their actions - a cognitive move he termed the "agentic shift" (1974). Similarly, the classic studies on the bystander effect show how the presence of others allows us to diffuse our responsibility to those in our vicinity (Darley \& Latané, 1968; Latané \& Darley, 1968). These classic studies show how easily we treat moral responsibility for undesirable outcomes like a hot potato: easily thrown to anyone within range.

We also misattribute responsibility for our actions to those whom we harm. Calling Starbucks a "bad ... money sucking organization" allowed my MBA student to reframe newspaper theft as a justified act initiated by Starbucks' own greed. In a more heinous example of blaming the victim, Paul Meadlo, one of the primary perpetrators of the My Lai massacre (an incident during the American conflict with Vietnam in which a few US soldiers killed several hundred civilians), reported shortly afterward that the massacre "did take a load off my conscience" because it represented "revenge ... for the buddies we'd lost" (Hersh, 2015). When we cast ourselves as victims of other's prior misdeeds, we are more able to hold on to the belief that we deserve no blame for our misbehavior (Zitek, Jordan, Monin, \& Leach, 2010). In addition, construing victims as undeserving of kind or respectful treatment facilitates perceiving our actions against them as moral because they "deserve" it. 
If we trick ourselves into thinking that we are not the causal agent of our actions, we can forgive ourselves for engaging in it, leaving our moral self-image untarnished. A compelling study that included indepth interviews with several bystanders during the Holocaust found they described their inaction as predetermined: they believed doing nothing was their only possible course of action (Monroe, 2001). Of course, this conviction flies in the face of the hundreds of similar others who risked their own lives to rescue endangered others (and who, interestingly, also describe their actions as predetermined). However, conceiving of the decision to do nothing as the only possible course of action while millions were murdered for their faith or other differences permitted immunity from feeling responsible for what their inaction let happen. It also allowed them to believe that their inaction did not undermine their identity as moral individuals: if there was nothing else they could have done, then their identity as moral individuals remained unthreatened (Monroe, 2008).

(5) Taking advantage of ambiguity to construe behavior as morally innocuous. Our circumstances often have characteristics that facilitate ambiguous interpretations of our actions. When situational ambiguity is present, we tend to interpret available cues and information in ways that paint ourselves in the best light. For example, when evaluating what traits one possesses, individuals take advantage of ambiguity in the definitions of positive and negative traits to ensure that they can be most associated with positive traits and distanced from negative ones (Dunning, Meyerowitz, \& Holzberg, 1989). In assessing whether one is moral, for example, an individual gives preferential weight to their charitable work (using "charitable" as a defining characteristic of the trait "moral"), and minimizes those times they misrepresented their income on their tax forms (failing to use "honest" as a defining characteristic of the trait "moral").

Situational ambiguity can be exploited to an actor's advantage, facilitating problematic behavior while allowing the individual to interpret it in a more flattering way. Snyder and colleagues documented this in the domain of discrimination using an experimental paradigm in which individuals had to choose how far to sit from someone who was disabled (Snyder, Kleck, Strenta, \& Mentzer, 1979). There was a choice of two seats, each in front of a television. One seat was beside a disabled person, the other farther away. In one condition, the televisions were showing the same program, and in the other they were showing different programs. Not wanting to appear prejudiced, individuals largely chose to sit near the disabled person when the televisions were showing the same program, but largely chose to sit farther from him when the programs were different. 
Different programs created an ambiguity about the participants' motives in choosing to sit farther away, that allowed them to behave prejudicially without seeming that they were.

Work on moral hypocrisy provides another good example of how we can exploit situational ambiguity to "appear moral to oneself without being so" (Batson, Thompson, Seuferling, Whitney, \& Strongman, 1999). In these studies, participants were informed the experiment involved two tasks that they had to delegate between themselves and another participant. One task was long and boring and the other was fun and came with the opportunity to win an additional financial bonus. When participants were informed that prior participants had rated a coin flip as the fairest way to assign the tasks, half chose to do so, yet $90 \%$ of these coin-flipping participants somehow ended up with the fun task (Batson, Kobrynowicz, Dinnerstein, Kampf, \& Wilson, 1997). By not specifying in advance which side of the coin meant that they would undertake the fun task, participants were free to interpret the result of any coin toss in a way more favorable to themselves, while appearing fair (for an overview, see Chapter 2, this volume).

Ambiguity also allows us to trick ourselves more easily into thinking that our actions do not fit problematic moral categories. Like the MBA student who was able to construe "taking the newspaper from Starbucks" as not belonging to the category of theft, Mazar and colleagues' tested "categorical malleability" as an amplifier of unethical behavior. They found that participants were more likely to dishonestly report their performance when they earned tokens for correct answers rather than money, even though the participants knew that they were going to exchange the tokens 1:1 for money at the end of the experiment (Mazar et al., 2008). In the researcher's view, using tokens as a medium between overreporting their performance and actually taking unearned money for it increased unethical behavior because it seemed less like theft to take extra tokens, and then convert those tokens into cash, than to take the extra cash outright.

Another type of ambiguity involves "wiggle room." In a series of experiments, Schweitzer and Hsee (2002) manipulated the wiggle room sellers in a negotiation had to misrepresent key elements of the negotiation to buyers. For example, in one study participants were told to sell a used car for which accurate mileage information was unavailable, but that the buyers were likely to believe the car had 60,000 miles on it. In one condition they were told that the mileage of the car was between 74,000 and 76,000 , and in a second condition they were told that the mileage was between 60,000 and 90,000. This second condition gave participants the wiggle room of a wider range of mileage, and hence participants were 
much more likely to report that the actual mileage of the car was 60,000 (Schweitzer \& Hsee, 2002). In another series of experiments designed to test wiggle room, Dana and colleagues (2007) adapted a standard dictator game in a number of ways to make the role of the dictator in making unfair allocations more opaque. In the standard paradigm, three quarters of participants chose to distribute $\$ 10$ between themselves and the recipient equally. However, in each of the three additional conditions that introduced ambiguity about whether the dictators allocated fairly or not, the proportion of dictators who did so halved (Dana et al., 2007).

Examples from the real world show how easy it is to take advantage of situational ambiguity in order to further selfish agendas. For example, Carmen Segarra, a recent whistleblower at the New York Federal Reserve, exposed how Goldman Sachs was operating without a comprehensive and articulated policy to define and manage conflicts of interest. Without a clear, written conflict of interest policy that applied to all divisions of the bank, Goldman bankers had the procedural wiggle room to operate on both sides of a deal. Representing both the buyer and the seller in a transaction creates a conflict of interest because the motivations of each cannot be kept confidential, and the fiduciary duty of undivided loyal to one's client becomes divided. When Segarra asked Goldman executives how such conflicts were managed, they pointed to "briefings" of the parties to the transaction, and an invisible "Chinese Wall" between the bankers on either side of the deal. In reality, the ambiguity created by the lack of a comprehensive policy facilitated interpreting these measures as an effective way to manage such conflicts of interest, when in fact they were not (Bernstein, 2013, 2014).

Together, the work described in this section shows that engaging in an unethical act - from cheating to stealing the newspaper at Starbucks to following military orders to kill civilians - triggers us to seek understandings of that act as consonant with our beliefs, even if that means deceiving ourselves about our original views about the moral status of the act. It also underscores the importance of cognitive dissonance in the relationship between self-deception and unethical behavior. Since it is aversive to think of ourselves as unethical, when we do behave unethically, we seek ways to square having done this with our understanding of ourselves as moral. If this requires that we change our beliefs about the moral status of our actions, we are more than happy to comply. As Private First Class Paul Meadlo described his participation in My Lai, where he estimates he killed 15 civilians, "At the time it didn't bother me. We all thought we were doing the right thing" (Hersh, 2015). Clearly, from an outsider's perspective, Meadlo was deceiving himself about the moral status of his actions. However, the drive to reduce the dissonance triggered by the 
discrepancy between what he did and his need to believe that what he did was the right thing made it possible for him to construe his participation in the massacre as moral. So long as we can redefine our actions as moral, we can deceive ourselves into thinking that any atrocity we engage in is acceptable.

\section{Motivated recall}

The third way that self-deception supports unethical behavior is through faulty encoding and retrieval of our past actions. Research has shown robustly how faulty human memory is (Walker, Skowronski, \& Thompson, 2003). Time allows us to forget action that we would rather not remember. Or, if forced to recall them, time also gives us the space to invent more self-serving explanations for having participated in them. Self-serving attributions are exacerbated in hindsight, such that we make even more external attributions for negative outcomes when we recall them a few days later than when we do so immediately after the event (Burger, 1986). Biased memory is particularly evident in the moral domain (Tenbrunsel et al., 2010). Since it is so important both to believe we are ethical and to recall our prior actions as consistent with how we see ourselves, prior transgressions will be recalled less often than prior good deeds, and when we do recall prior transgressions, both the acts and our involvement in them will have morphed into something more forgiving to our moral self-image.

(6) Forgetting what we'd rather not know. Since we are threatened by feedback that has unfavorable implications for our self-image, poor recall of this information facilitates our ability to think of our past behavior in a positive light. Sedikides, Green and colleagues have studied how individuals exhibit poorer recall of self-relevant information that is negative even though we recognize this information as easily as self-relevant positive information (Green, Sedikides, \& Gregg, 2008; Sedikides \& Green, 2004, 2009). However, this bias is eliminated when individuals have affirmed the self prior to recalling the events, suggesting that our selective recall of information that reflects poorly on us is motivated by our general need to self-enhance (Green et al., 2008). In fact, we remember in greater detail personal history about which we are proud, compared to personal history about which we are ashamed, even though we do not show the same bias when recalling stories about others about whom we feel admiration and contempt (D'Argembeau \& Van der Linden, 2008).

Perhaps the tendency to forget prior actions that threaten our moral self-image explains why former US President Ronald Reagan's Congressional testimony regarding his involvement in the Iran-Contra 
scandal is so liberal in its use of the phrase "I don't recall" (Chicago Tribune, 1990). While there were certainly important legal and public relations advantages to Reagan's poor recall about his role in the IranContra affair, his recall failures are also useful in maintaining his moral self-image, supporting the belief that he was uninvolved in the scandal. Higher levels of selective memory are associated with lower levels of social anxiety, suggesting there is something adaptive about forgetting what we would rather not remember (O'Banion \& Arkowitz, 1977). In fact, we get better at distorting our memories as we get older. Older adults show more "emotionally gratifying memory distortion" than younger adults (Mather $\&$ Carstensen, 2005), suggesting that self-deception in memory and recall may be part of an adaptive process that allows us to maintain a more even emotional keel as we age.

The clearest effort to show that we are motivated to forget what we would rather not remember in terms of our unethical behavior documents how individuals "forget" moral rules (such as elements of an honor code) after cheating, even though they are no less likely to "forget" other pieces of information (such as facts from a training manual) (Shu \& Gino, 2012; Shu, Gino, \& Bazerman, 2011). If we can't remember the principle we violate, we didn't violate the principle (at least to the best of our memory). These findings are supported by recent research in neurobiology that documents that we can actively forget unwanted memories at a neural level (Anderson et al., 2004). In other words, part of our brain chemistry is designed to keep things we would rather not know outside of our conscious awareness.

(7) Fabricating alternate histories. We not only proactively forget what we would rather not remember. We also "remember" versions of the past that never existed. For example, research suggests that individuals come to believe fabrications about past events, and that their "memory" of these past events gains traction over time (Chrobak \& Zaragoza, 2008; Gonsalves \& Paller, 2002; Gonsalves et al., 2004). In one study, participants watched a video and were then asked to recall specific scenes that did not exist. Immediately following the videos, the majority of participants denied having watched the fabricated scene. However, two months later, $50 \%$ of them freely reported remembering details from these scenes they'd never watched (Chrobak \& Zaragoza, 2008). Once the idea of an alternate history is suggested to us, it germinates in our memory and slowly becomes more real. Moreover, the idea of an alternate history may be particularly attractive for us to think about if we regret prior unethical behavior, planting the seeds of later fabrication to take root.

One can see how our need to see ourselves as moral might cause us to imagine alternatives to actual past misdeeds, leading to 
"remembering" a wrong - though self-serving - version of events. In a regrettable instance from my own past, I once sublet my bedroom in my New York City apartment to a perfectly nice young woman for the summer. I didn't return her deposit when I returned in September. My "memory" of this event was that our original agreement had been that she would pay a deposit to cover the costs of her wear and tear on the room. It was only when catching up with my old roommate from that time (who chided me for my unfairness to her) that I realized I had fabricated the agreement that her deposit would cover those costs, and in fact I had failed to return her deposit for no good reason at all. Unfortunately, most of the time, once we've sanitized our past behavior by inventing a preferred reality, we typically have no reason to challenge ourselves with the truth again.

\section{Is self-deception about unethical behavior adaptive?}

Individuals who are adept at self-deception (measured as a disposition) show higher rates of athletic success (Starek \& Keating, 1991), higher levels of pain tolerance (Jamner \& Schwartz, 1986) and a greater ability to withstand stress (Linden, Paulhus, \& Dobson, 1986). Dispositional selfdeception even predicts mating success among women (Lynn, Pipitone, $\&$ Keenan, 2014). In addition, as the research overviewed in this chapter makes clear, misplaced optimism about our morality seems adaptive as well. If, as Trivers argues (2000), the value of self-deception is the decreased cognitive load of believing the truth while propagating a falsehood, then unethical behavior will be made cognitively easier of one can actively misrepresent the action to ourselves as morally appropriate. Providing some evidence in support of this perspective, ethics-related concepts appear to be less cognitively accessible to individuals who cheat (Shu \& Gino, 2012). Certainly, deceiving oneself about the moral status about an act seems useful in successfully defending oneself to others, as in Ronald Regan's limited ability to recall many aspects of his involvement in the Iran-Contra affair.

Ultimately, the most important audience for self-deception about one's (im)moral actions may be oneself. In a series of experiments by Chance and colleagues (2011), individuals who were provided with the answers to a series of questions testing their general knowledge and IQ attributed their higher levels of performance (compared to those without the benefit of seeing the answers) to their own abilities rather than the unfair advantage they had by seeing the answers (Chance, Norton, Gino, \& Ariely, 2011). Moreover, this bias toward overestimating one's abilities was resistant to interventions designed to increase self-assessment accuracy, 
and the tendency to overestimate one's abilities was higher for those who were higher in dispositional self-deception. There seems to be something specifically adaptive about this type of self-deceit: it allows us to feel good about ourselves without doing the work, an attractive proposition for our baser instincts.

A confluence of factors leads to a perfect storm facilitating self-deception as a critical process supporting unethical behavior. We have a strong desire to believe that we are moral but often cheat, lie, steal, or take other moral shortcuts in order to gain something for ourselves we do not deserve. Our ability to misrepresent reality to ourselves so that we can believe the best of ourselves while engaging in unethical behavior allows us to have our cake (a positive moral self-image) and eat it too (the benefits that unethical behavior can provide). The extent to which selfdeception allows us to maintain our positive moral self-image while behaving in ways that ought to tarnish it makes it unsurprising that another correlate of dispositional self-deception is individuals' selfreports of how moral they are (Lu \& Chang, 2011).

In this chapter, I have described a number of ways in which individuals actively misrepresent reality to themselves so that we remain the heroes of our own narratives, even as we act in ways that are less than heroic. I have called this phenomenon self-deception, though I concede that some of the phenomena I describe do not meet strict criteria for self-deception (those that require holding two inconsistent beliefs simultaneously in one's conscious mind). As the research I have discussed shows, the human mind is more creative than the philosophers who originally worried about the logical fallacy of true self-deception considered. Self-deception of this variety - attending only to (or even creating) information that supports positive narratives about how moral we are, manipulating our beliefs about our actions or our agency to ensure that we construe what we do as moral, or recalling our past actions with rose-colored glasses - all support being able to take advantage of unethical behavior without tarnishing our moral self-image. For a number of psychologically adaptive reasons, we are proficient at tricking ourselves into believing that we are the heroes of our own narratives, even when our actions indicate clearly otherwise.

\section{References}

Allison, S. T., Messick, D. M., \& Goethals, G. R. (1989). On being better but not smarter than others: The Muhammad Ali effect. Social Cognition, 7, 275-295. Anderson, M. C., Ochsner, K. N., Kuhl, B., Cooper, J., Robertson, E., Gabrieli, S. W., ... Gabrieli, J. D. E. (2004). Neural systems underlying the suppression of unwanted memories. Science, 303, 232-235. 
Ariely, D. (2012). The (honest) truth about dishonesty: How we lie to everyoneespecially ourselves. New York: Harper.

Arkin, R., Cooper, H., \& Kolditz, T. (1980). A statistical review of the literature concerning the self-serving attribution bias in interpersonal influence situations. Fournal of Personality, 48, 435-448.

Bandura, A. (1990). Mechanisms of moral disengagement. In W. Reich (Ed.), Origins of terrorism: Psychologies, ideologies, states of mind (pp. 161-191). New York: Cambridge University Press.

Bandura, A. (1991). Social cognitive theory of moral thought and action. In W. M. Kurtines \& J. L. Gewirtz (Eds.), Handbook of moral behavior and development (Vol. 1, pp.45-103). Hillsdale, NJ: Erlbaum.

Bandura, A. (2011). Self-deception: A paradox revisited. Behavioral and Brain Sciences, 34, 16-17.

Batson, C. D., Kobrynowicz, D., Dinnerstein, J. L., Kampf, H. C., \& Wilson, A. D. (1997). In a very different voice: Unmasking moral hypocrisy. Fournal of Personality and Social Psychology, 72, 1335-1348.

Batson, C. D., Thompson, E. R., Seuferling, G., Whitney, H., \& Strongman, J. A. (1999). Moral hypocrisy: Appearing moral to oneself without being so. Fournal of Personality and Social Psychology, 77, 525-537.

Bernstein, J. (2013, October 10). NY fed fired examiner who took on Goldman. ProPublica. Retrieved from: www.propublica.org/article/ny-fed-fired-exami ner-who-took-on-goldman.

Bernstein, J. (2014, September 26). Inside the New York Fed: Secret recordings and a culture clash. ProPublica. Retrieved from: www.propublica.org/article/ carmen-segarras-secret-recordings-from-inside-new-york-fed.

Bersoff, D. M. (1999). Why good people sometimes do bad things: Motivated reasoning and unethical behavior. Personality and Social Psychology Bulletin, $25,28-39$.

Blasi, A. (1984). Moral identity: Its role in moral functioning. In W. Kurtines \& J. Gewirtz (Eds.), Morality, moral behavior and moral development (pp. 128139). New York: Wiley.

Burger, J. M. (1986). Temporal effects on attributions: Actor and observer differences. Social Cognition, 4, 377-387.

Callahan, D. (2004). The cheating culture: Why more Americans are doing wrong to get ahead. New York: Harcourt.

Chance, Z., Norton, M. I., Gino, F., \& Ariely, D. (2011). Temporal view of the costs and benefits of self-deception. Proceedings of the National Academy of Sciences, 108 (Supplement 3), 15655-15959.

Chicago Tribune. (1990, February 23). "I Don`t Recall” marks excerpts of Reagan testimony. Retrieved from: http://articles.chicagotribune.com/1990-02-23/n ews/9001160085_1_john-poindexter-recall-reagan-testimony.

Chrobak, Q., \& Zaragoza, M. (2008). Inventing stories: Forcing witnesses to fabricate entire fictitious events leads to freely reported false memories. Psychonomic Bulletin \& Review, 15, 1190-1195.

Cooper, J. (2007). Cognitive dissonance: Fifty years of a classic theory. Los Angeles: Sage. 
D'Argembeau, A., \& Van der Linden, M. (2008). Remembering pride and shame: Self-enhancement and the phenomenology of autobiographical memory. Memory, 16, 538-547.

Dana, J., Weber, R., \& Kuang, J. (2007). Exploiting moral wiggle room: Experiments demonstrating an illusory preference for fairness. Economic Theory, 33, 67-80.

Darley, J. M., \& Latané, B. (1968). Bystander intervention in emergencies: Diffusion of responsibility. Fournal of Personality and Social Psychology, 8, 377-383.

Dawson, E., Savitsky, K., \& Dunning, D. (2006). “Don't tell me, I don't want to know": Understanding people's reluctance to obtain medical diagnostic information. Fournal of Applied Social Psychology, 36, 751-768.

Ditto, P. H., \& Lopez, D. F. (1992). Motivated skepticism: Use of differential decision criteria for preferred and nonpreferred conclusions. Fournal of Personality and Social Psychology, 63, 568-584.

Ditto, P. H., Munro, G. D., Apanovitch, A. M., Scepansky, J. A., \& Lockhart, L. K. (2003). Spontaneous skepticism: The interplay of motivation and expectation in responses to favorable and unfavorable medical diagnoses. Personality and Social Psychology Bulletin, 29, 1120-1132.

Dunning, D., Meyerowitz, J. A., \& Holzberg, A. D. (1989). Ambiguity and self-evaluation: The role of idiosyncratic trait definitions in self-serving assessments of ability. Fournal of Personality and Social Psychology, 57, 1082-1090.

Ehrich, K. R., \& Irwin, J. R. (2005). Willful ignorance in the request for product attribute information. Fournal of Marketing Research, 42, 266-277.

Festinger, L. (1957). A theory of cognitive dissonance. Evanston, IL: Row, Peterson.

Festinger, L., \& Freedman, J. (1964). Dissonance reduction and moral values. In S. Worchel \& D. Byrne (Eds.), Personality change (pp. 220-247). New York: Wiley.

Fingarette, H. (1969). Self-deception. New York: Humanities Press.

Forsyth, D. R., Pope, W. R., \& McMillan, J. H. (1985). Students' reactions after cheating: An attributional analysis. Contemporary Educational Psychology, 10, $72-82$.

Freud, S. (1900/1955). The interpretation of dreams. New York: Basic Books.

Gabor, T. (1994). Everybody does it: Crime by the public. Toronto, Canada: University of Toronto Press.

Gonsalves, B., \& Paller, K. A. (2002). Mistaken memories: Remembering events that never happened. The Neuroscientist, 8, 391-395.

Gonsalves, B., Reber, P. J., Gitelman, D. R., Parrish, T. B., Mesulam, M.-M., \& Paller, K. A. (2004). Neural evidence that vivid imagining can lead to false remembering. Psychological Science, 15, 655-660.

Green, J. D., Sedikides, C., \& Gregg, A. P. (2008). Forgotten but not gone: The recall and recognition of self-threatening memories. Fournal of Experimental Social Psychology, 44, 547-561.

Greenwald, A. G. (1980). The totalitarian ego: Fabrication and revision of personal history. American Psychologist, 35, 603-618. 
Gur, R. C., \& Sackeim, H. A. (1979). Self-deception: A concept in search of a phenomenon. Fournal of Personality and Social Psychology, 37, 147-169.

Haight, M. R. (1980). A study of self-deception. Atlantic Highlands, NJ: Humanities Press.

Hays, T., \& Neumeister, L. (2013, November 12). Longtime madoff employee tells jury he didn't ask questions as fraud grew. Associated Press. Retrieved from: www.ctvnews.ca/business/longtime-madoff-employee-tells-jury-he-didn-t-askquestions-as-fraud-grew-1.1539144.

Hersh, S. M. (2015, March 30). The scene of the crime: A reporter's journey to My Lai and the secrets of the past. New Yorker. Retrieved from: www.newyorker .com/magazine/2015/03/30/the-scene-of-the-crime.

Hill, C., Memon, A., \& McGeorge, P. (2008). The role of confirmation bias in suspect interviews: A systematic evaluation. Legal and Criminological Psychology, 13, 357-371.

Jamner, L. D., \& Schwartz, G. E. (1986). Self-deception predicts self-report and endurance of pain. Psychosomatic Medicine, 48, 211-223.

Kunda, Z. (1987). Motivated inference: Self-serving generation and evaluation of causal theories. Fournal of Personality and Social Psychology, 53, 636-647.

Latané, B., \& Darley, J. M. (1968). Group inhibition of bystander intervention in emergencies. Fournal of Personality and Social Psychology, 10, 215-221.

Levy, N. (2004). Self-deception and moral responsibility. Ratio, 17, 294-311.

Linden, W., Paulhus, D. L., \& Dobson, K. S. (1986). Effects of response styles on the report of psychological and somatic distress. Fournal of Consulting and Clinical Psychology, 54, 309-313.

Lu, H. J., \& Chang, L. (2011). The association between self-deception and moral self-concept as functions of self-consciousness. Personality and Individual Differences, 51, 845-849.

Lynn, C. D., Pipitone, R. N., \& Keenan, J. P. (2014). To thine own self be false: Self-deceptive enhancement and sexual awareness influences on mating success. Evolutionary Behavioral Sciences, 8, 109-122.

Martin, M. W. (1986). Self-deception and morality. Lawrence, KS: University Press of Kansas.

Mather, M., \& Carstensen, L. L. (2005). Aging and motivated cognition: The positivity effect in attention and memory. Trends in Cognitive Sciences, 9, 496-502.

Mazar, N., Amir, O., \& Ariely, D. (2008). The dishonesty of honest people: A theory of self-concept maintenance. Fournal of Marketing Research, 45, 633-644.

Mele, A. R. (2001). Self-deception unmasked. Princeton, NJ: Princeton University Press.

Messick, D. M., Bloom, S., Boldizar, J. P., \& Samuelson, C. D. (1985). Why we are fairer than others. Fournal of Experimental Social Psychology, 21, 480-500.

Milgram, S. (1974). Obedience to authority: An experimental view. New York: Harper \& Row.

Miller, D. T. (1976). Ego involvement and attributions for success and failure. Fournal of Personality and Social Psychology, 34, 901-906. 
Miller, D. T., \& Ross, M. (1975). Self-serving biases in the attribution of causality: Fact or fiction? Psychological Bulletin, 82, 213-225.

Mills, J. (1958). Changes in moral attitudes following temptation. Fournal of Personality, 26, 517-531.

Monroe, K. R. (2001). Morality and a sense of self: The importance of identity and categorization for moral action. American fournal of Political Science, 45, 491-507.

Monroe, K. R. (2008). Cracking the code of genocide: The moral psychology of rescuers, bystanders, and nazis during the holocaust. Political Psychology, 29, 699-736.

Moore, C. (2015). Moral disengagement. Current Opinion in Psychology, 6, 199-204.

New York Times. (2006, April 27). Lay blames Enron failure on attack of shortsellers. Retrieved from: www.nytimes.com/2006/04/27/business/worldbusi ness/27iht-enron.html?_r $=0$.

Nickerson, R. S. (1998). Confirmation bias: A ubiquitous phenomenon in many guises. Review of General Psychology, 2, 175-220.

O'Banion, K., \& Arkowitz, H. (1977). Social anxiety and selective memory for affective information about the self. Social Behavior and Personality, 5, 321-328.

O'Brien, B. (2009). Prime suspect: An examination of factors that aggravate and counteract confirmation bias in criminal investigations. Psychology, Public Policy, and Law, 15, 315-334.

Quattrone, G. A., \& Tversky, A. (1984). Causal versus diagnostic contingencies: On self-deception and on the voter's illusion. Fournal of Personality and Social Psychology, 46, 237-248.

Rick, S., Loewenstein, G., Monterosso, J. R., Langleben, D. D., Mazar, N., Amir, O., \& Ariely, D. (2008). Commentaries and rejoinder to "The Dishonesty of Honest People." Fournal of Marketing Research, pp. 645-653.

Schweitzer, M. E., \& Hsee, C. K. (2002). Stretching the truth: Elastic justification and motivated communication of uncertain information. The fournal of Risk and Uncertainty, 25, 185-201.

Sedikides, C., \& Green, J. D. (2004). What I don't recall can't hurt me: Information negativity versus information inconsistency as determinants of memorial self-defense. Social Cognition, 22, 4-29.

Sedikides, C., \& Green, J. D. (2009). Memory as a self-protective mechanism. Social and Personality Psychology Compass, 3, 1055-1068.

Shalvi, S., Dana, J., Handgraaf, M. J. J., \& De Dreu, C. K. W. (2011). Justified ethicality: Observing desired counterfactuals modifies ethical perceptions and behavior. Organizational Behavior and Human Decision Processes, 115, 181-190.

Shu, L. L., \& Gino, F. (2012). Sweeping dishonesty under the rug: How unethical actions lead to forgetting of moral rules. Fournal of Personality and Social Psychology, 102, 1164-1177.

Shu, L. L., Gino, F., \& Bazerman, M. H. (2011). Dishonest deed, clear conscience: When cheating leads to moral disengagement and motivated forgetting. Personality and Social Psychology Bulletin, 37, 330-349. 
Snyder, M. L., Kleck, R. E., Strenta, A., \& Mentzer, S. J. (1979). Avoidance of the handicapped: An attributional ambiguity analysis. Fournal of Personality and Social Psychology, 37, 2297-2306.

Starek, J. E., \& Keating, C. F. (1991). Self-deception and its relationship to success in competition. Basic and Applied Social Psychology, 12, 145-155.

Stewart, J. B. (2007, February 19 \& 26). The Kona Files: How an obsession with leaks brought scandal to Hewlett-Packard. The New Yorker, 152-167.

Sweeny, K., Melnyk, D., Miller, W., \& Shepperd, J. A. (2010). Information avoidance: Who, what, when, and why. Review of General Psychology, 14, 340-353.

Taylor, S. E. (1991). Asymmetrical effects of positive and negative events: The mobilization-minimization hypothesis. Psychological Bulletin, 110, 67-85.

Tenbrunsel, A. E., Diekmann, K. A., Wade-Benzoni, K. A., \& Bazerman, M. H. (2010). The ethical mirage: A temporal explanation as to why we are not as ethical as we think we are. Research in Organizational Behavior, 30, 153-173.

Tenbrunsel, A. E., \& Messick, D. M. (2004). Ethical fading: The role of selfdeception in unethical behaviour. Social fustice Research, 17, 223-236.

Trivers, R. (2000). The elements of a scientific theory of self-deception. Annals of the New York Academy of Sciences, 907, 114-131.

Van Lange, P. A. M., \& Sedikides, C. (1998). Being more honest but not necessarily more intelligent than others: Generality and explanations for the Muhammad Ali effect. European fournal of Social Psychology, 28, 675-680.

von Hippel, W., \& Trivers, R. (2011). The evolution and psychology of selfdeception. Behavioral and Brain Sciences, 34, 1-16.

Walker, W. R., Skowronski, J. J., \& Thompson, C. P. (2003). Life is pleasant-and memory helps to keep it that way! Review of General Psychology, 7, 203-210.

Zitek, E. M., Jordan, A. H., Monin, B., \& Leach, F. R. (2010). Victim entitlement to behave selfishly. Fournal of Personality and Social Psychology, 98, 245-255.

Zuckerman, M. (1979). Attribution of success and failure revisited, or: The motivational bias is alive and well in attribution theory. Fournal of Personality, 47, 245-287. 